IJCRR

Section: Healthcare ISI Impact Factor (2019-20): 1.628

IC Value (2019): 90.81 $\operatorname{SJIF}(2020)=7.893$

(c) (i) (8) Copyright@IJCRR

\section{$\bullet$ \\ Ayurvedic Management of Myopia in Children: A Case Series}

\section{Sreekanth Nelliakkattu Parameswaran¹, Ratna Prava Mishra ${ }^{2}$, Jaya Sankar Mund ${ }^{3}$}

Ph.D Scholar, Mandsaur lnstitute of Ayurved Education and Research, Mhow-Neemuch Road, B R Nahata Marg, Opp. To Krishi Upaj Mandi, Mandsaur, Madhya Pradesh - 458001, India; ${ }^{2}$ Professor and Head, Department of Kayacikitsa (Internal Medicine), Mandsaur Institute of Ayurved Education and Research, Mhow- Neemuch Road, B R Nahata Marg, Opp. To Krishi Upaj Mandi, Mandsaur, Madhya Pradesh 458001, India; 3Ph.D, Principal, Mandsaur Institute of Ayurved Education and Research, Mhow- Neemuch Road, B R Nahata Marg, Opp. To Krishi Upaj Mandi, Mandsaur, Madhya Pradesh - 4580o1, India.

\title{
ABSTRACT
}

Introduction: Myopia is one of the leading causes of visual impairment in schoolchildren. The most common management option, prescription of corrective spectacles, neither correct nor prevent progression of the error. The cardinal symptom of myopia, the inability to see distant objects, may be compared with Timira (blurring of vision) in Ayurveda.

Case Series: The cases of three children who presented to Sreedhareeyam Ayurvedic Eye Hospital with the blurring of vision and who were diagnosed with myopia are presented here.

Intervention: The children underwent specially tailored Ayurvedic treatment protocols, which included oral medicines, Netra Kriyakalpa (ocular therapeutics), and treatments for the head.

Results: Improvement in visual acuity and refraction was observed at the end of the treatments. Multiple follow-ups demonstrated either improvement or maintenance of visual acuity.

Conclusion: The main challenge for the patients was maintaining and improving vision. The results of the series indicate the potential of Ayurvedic treatments to both manage myopia and to maintain, and improve in some cases, vision in children.

Key Words: Ayurveda, Case report, Timira, Kriyakalpa, Complementary and alternative medicine, Refractive error

\section{INTRODUCTION}

Vision 2020: The Right to Sight contends that uncorrected refractive errors are among the top causes of visual impairment and blindness. ${ }^{1}$ Myopia is the leading cause of visual impairment in children among the three types of refractive error, with a rapid increase in prevalence. ${ }^{2}$ Myopia presents a significant impact on an individual's quality of life as well as the economy. ${ }^{3}$ Research on causal factors, possible treatments, and efforts at prevention have been spurred in light of the increasing incidence and prevalence of myopia. ${ }^{4}$ The aetiology of myopia is multifactorial as per the Consortium for Refractive Error and Myopia (CREAM) study, which demonstrated 24 genomes with a 10 -fold increase in myopia. ${ }^{5}$ Conventional management options for myopia have either short-term benefits or significant side effects. ${ }^{6}$ Although significant strides have been made in the field of surgical correction, they might not always be effective in the tender and delicate eyes of children. In light of the above, treatment options in contemporary and alternative medicine (CAM), including Ayurveda, may be sought.

\section{METHODOLOGY}

The cases of three children diagnosed with myopia and who underwent Ayurvedic eye treatments are presented in this series. Points regarding their history were given by their legal guardians. The CARE guidelines were adhered to for ensuring transparency and effectiveness in reporting. ${ }^{7}$ Written informed consent was obtained from the parents. Institutional ethics committee clearance was not required to prepare this series.

\section{Case 1}

A 9-year-old male patient presented with a complaint of defective distant vision for 7 months. His parents reported

\section{Corresponding Author:}

Sreekanth Nelliakkattu Parameswaran, M.S. (Ay), Ph.D Scholar, Mandsaur Institute of Ayurved Education and Research, Mhow- Neemuch Road, B R Nahata Marg, Opp. To Krishi Upaj Mandi, Mandsaur, Madhya Pradesh - 458001, India.

ISSN: 2231-2196 (Print)

Received: 28.10 .2020
ISSN: 0975-5241 (Online)

Revised: 04.01 .2021
Accepted: 17.03 .2021
Published: 20.07 .2021 
watching TV very closely and his inability to read small letters on the chalkboard from a distance. He was diagnosed with myopia by an ophthalmologist and was prescribed corrective spectacles, which he never used. In September 2017, he started Ayurvedic medication from Sreedhareeyam Hospital, which provided better clarity in vision. Hence, he came for further management. His history was negative for significant illnesses. His mother had a full-term normal delivery and he achieved all cardinal milestones on time. His immediate family members do not present with similar complaints, and his history readings were normal. A review of systems showed normal cardiovascular, gastrointestinal and neurological functions, and vital signs were all normal.

Unaided distant visual acuity (DVA) was LogMAR 0.602 in his right eye (OD - oculus dexter) and LogMAR 1 in his left eye (OS - oculus sinister), and near visual acuity (NVA) was N6 in both eyes (OU - oculus uterque). Pinhole acuity was not determined. Manual refraction showed that a -0.50 diopter (D) lens with $-3.00 \mathrm{D}$ cylinder and $10^{\circ}$ axis corrected the DVA OD to LogMAR 0.176, and a -1.50D lens with -3.00D cylinder and $160^{\circ}$ axis corrected the DVA OS to LogMAR 0.477. Anterior segment examination OU showed normal lids and sclera, normal cornea, deep anterior chamber, and a normal lens. Direct and consensual pupillary reflexes were normal OU. Posterior segment examination OU showed normal media, optic disc, background, and blood vessels. Corneal topography OU demonstrated with-the-rule astigmatism. The patient was admitted for a 15-day course of inpatient Ayurvedic treatment.

Unaided DVA at discharge showed improvement to LogMAR 0.778 OS, while DVA OD was maintained. Manual refraction demonstrated the same readings as found on admission.

\section{Case 2}

A 6-year-old male presented with a complaint of diminished distance vision for 8 months. His parents noticed difficulty in seeing distant objects and inability to read the letters off the chalkboard. He was diagnosed with myopia and was prescribed corrective spectacles, which he still uses but does not provide enough relief. Hence, he came here for better options. His history was negative for any significant illnesses. His mother had given birth to him after thirteen years of marriage, for which she had taken treatment for infertility. $\mathrm{He}$ was delivered by lower-segment Caesarean section, and he achieved all his milestones on time. His immediate family members do not complain of similar illnesses. His history readings are normal. A review of systems showed normal cardiovascular, gastrointestinal, and neurological functions, and vital signs were all normal.

Unaided DVA showed LogMAR 0.477 OD and LogMAR 0.176 OS, and NVA was N6 OU. Pinhole acuity and refrac- tion were not attempted. Anterior segment examination OU showed normal lids and sclera, normal cornea, deep anterior chamber, and a normal lens. Direct and consensual pupillary reflexes were normal OU. Posterior segment examination OU showed normal media, optic disc, background, and blood vessels. The patient was admitted for a 19-day course of treatment.

Unaided DVA has maintained OU at discharge.

\section{Case 3}

A 9-year-old male complained of difficulty in the distant vision for 6 years. He noticed difficulty in reading the chalkboard from the back of the classroom. He was diagnosed with myopia and was prescribed corrective spectacles. He came to Sreedhareeyam seeking further options. His history is negative for any significant illnesses. His mother had a full-term normal delivery without postpartum complications. He attained all his milestones on time. His history readings are all normal. . Review of systems showed normal cardiovascular, gastrointestinal, and neurological functions, and vital signs were all normal.

Unaided DVA was LogMAR 0.301 OU, aided DVA was LogMAR 0 OU, and NVA was N6 OU. Anterior segment examination OU showed normal lids and sclera, normal cornea, deep anterior chamber, and a normal lens. Direct and consensual pupillary reflexes were normal OU. Posterior segment examination OU showed normal media, optic disc, background, and blood vessels. The patient was admitted for a 10-day course of treatment. All diagnostic readings were maintained at discharge.

\section{Additional Information}

Vulnerability assessment is done before treatment categorized the patients into the pediatric group with visual deficits. No history of disorientation, trauma, motility deficit and impaired judgment were elicited.

The patients' treatment protocols involved the administration of oral medicines (Table 1) and external ocular and head therapies (Table 2). Pancakarma (bio-purification) was not administered because the patients were under 10 years old.

All medicines, except Netra Prabha eye drops, were manufactured by Sreedhareeyam Farmherbs India, Pvt. Ltd., the hospital's GMP-certified drug manufacturing unit. $\mathrm{Ne}$ tra Prabha eye drops were manufactured by Jiwadaya Netraprabha Pharmaceuticals, Pvt., Ltd., based in Mumbai, Maharashtra, India.

\section{DISCUSSION}

The patients' symptoms were compared with Dvitiya Patalagata Dosha (affliction of the second layer of the eye by 
humors) as per the Ayurvedic classics. Acharya Vagbhata describes this condition as Timira. The feature of Timira that matches the symptoms of the patients is "DurantikasthamRupam ca (patient is unable to perceive distant objects)". Invasion of the third Patala is described as Timiraby AcharyaSusruta and Kacaby AcharyaVagbhata. ${ }^{2}$

Ayurveda contends that the same medicines and treatments prescribed for adults may be prescribed to children in a lower dosage and intensity. Mrdu (mild), Laghu (light), Madhura(sweet), Surabhi (pleasant odour), Samsamana (pacifying), and HetuViparita (antagonistic to the cause) are the qualities of the medicines generally favoured for children as these should not greatly affect Dhatus and be both palatable and easy to assimilate. Pancakarma, usually advocated in the management of DrishtigataRogas (diseases of vision) including Timira, is contraindicated in children, especially those under the age of 10. Also, the medicines employed should not be too Tikshna (sharp). These are due to the Saukumaryata (tender and delicate body structure), Alpakayata (under-developed organs), Vividha Anna Anupasevana (unfit GIT to receive all types of food), Aparipakva Dhatu (tissues under progression of transformation), AkleshaSahatva (stress intolerance), and AsampurnaBala (poor immunity). 5-8

The oral medicines were Cakshushya (good for eyes), Brmhana (nourishing), and Vata Hara (pacify Vata). In addition, Mustarishtaand Khadirarishtaare Agni Dipanaand were prescribed to maintain normal digestion in the children.

Netraraksha Kvatha, prepared from ingredients such as $C y$ perus rotundusLinn., Symplocosracemosus Roxb., Gmelina Arborea Linn., Aquilaria agallochaRoxb., and Emblica Officinalis Gaertn., is indicated in Netra Roga. MedhyaRasayanaisprepared from ingredients such as Tinospora cordifolia Miers., Centella Asiatica Linn., and Glycyrrhyza glabra Linn., and acts as a nerve tonic. Hrasva capsule, prepared from ingredients such as Vitis vinifera Linn., Symplocosracemosus Roxb., Hemidesmus indicus Linn., and Zingiber officinale Rosc., is indicated for all varieties of refractive error. SaptamrtaGhrta is prepared from Bacopa monnieriLinn., Hemidesmus indicus Linn., and HolarrhenaantidysentricaWall., is indicated in all eye diseases. VainateyaGhrta prepared from Glycyrrhyza glabra Linn., and Tinospora cordifolia Miers., is also indicated in all eye diseases. JatavedhaGhrta is prepared from Terminalia chebulaRetz., Terminalia bellericaLinn, Emblica Officinalis Gaertn., and HolostemmaadakodienR.Br., and is used for Tarpana in Drishti Rogas.Ananta Ghrta is prepared from Cedrus deodara Linn., and HoloostemmaadakodienR.Br., and is also used for Tarpana in Drishti Rogas. Sunetra Junior is prepared from $\mathrm{Ne}$ lumbo nucifera Gaertn., Ocimum sanctum Linn., Cinnamomum camphora(L.) Presl., and is indicated in eye conditions of patients under 16 years of age. Netra Prabha is prepared from Emblica Officinalis Gaertn., Argemone mexicana
Linn., and Cinnamomum Tamala(Buch-Ham) T. Nees., and is indicated in most inflammatory conditions of the eye..$^{3,4,5}$

Anjana was done in the manner of classical Ascyotana ${ }^{9}$ at Sreedhareeyam in light of hygienic parameters. Drishti Prasadanaand Tarpana was done to strengthen the nerves and to promote vision. The Sneha used for both procedures were Vata Hara. Anna Lepa was done for further pacification of Vata. ${ }^{8,9}$

\section{CONCLUSION}

The main challenge in the patients was the improvement of vision; however, improvement was observed due to healthy Dhatus being formed by the treatments and the bodies of the children acclimatizing to the medicines and treatments. Usage of medicines that were Brmhana, Samana, Mrdu, and Madhura, facilitated the formation of a healthy physique as well as strengthening the nerves. The results of this series may be validated with large-scale sample trials and studies.

\section{ACKNOWLEDGMENT}

The authors thank Sreedhareeyam Ayurvedic Research And Development Institute, Sreedhareeyam Ayurvedic Eye Hospital and Research Center, and SreedhareeyamFarmherbs India Pvt. Ltd., for their help in preparing this case report. The authors acknowledge the immense help received from the scholars whose articles are cited and included in references of this manuscript. The authors are also grateful to the authors/editors/publishers of all those articles, journals, and books from where the literature for this article has been reviewed and discussed.

Conflicts of Interest: None declared

Sources of Funding: None declared

\section{Authors' Contribution}

- Sreekanth P. Namboothiri conceptualized, wrote, and edited the article.

- Ratna Prava Misra and Jaya Sankar Mund reviewed and edited the article, and offered constructive feedback on the same.

\section{Abbreviations:}

DVA: distant visual acuity

NVA: near visual acuity

OD: oculus dexter

OS: oculus sinister

OU: oculus uterque 


\section{REFERENCES}

1. The International Agency for the Prevention of Blindness, Global Vision Impairment Facts, 2020, https://www.iapb.org/ vision-2020/who-facts/

2. Fricke TR, Jong M, Naidoo KS. The global prevalence of vision impairment associated with myopic macular degeneration and temporal trends from 2000-2050: systematic review, meta-analysis, and modelling, Bri J Med Sci, 2018;102(7): 855-862 pg.

3. Wong HB, Machin D, Tan SB, Wong TY, Saw SM. Visual impairment and its impact on health-related quality of life in adolescents, Asi J Organ, 2009;147(3);505-511 pg.

4. Mehta N, Wen A, Myopia: A Global Epidemic: An Overview of the Problem and Efforts to Address It. Retin.2019; 52-55 pg.

5. Smith TS, Frick KD, Holden BA, Fricke TR, Naidoo KS. Potential lost productivity resulting from the global burden of uncorrected refractive error, Bull World Health Organi. 2009;87(6):431-437.

6. Gwiazda J, Treatment options for myopia, OptomVis Sci, 2009; 89(6): 624-628 pgs

7. Gagnier J, Kienle G, Altman DG, Moher D, Sox H, Riley DS, CARE group, The CARE guidelines: Consensus-based clinical case-reporting guideline development, Glob Adv Health Me. 2013:2(5):38-43 pgs.

8. Murthy KR. Ashtangahrdaya of Vagbhata: Text, English Translation, Notes, Appendices, and Index, Vol. III: Uttara Sthana, Krishnadas Academy, Varanasi, 2000, 121pg

9. Murthy KR. Ashtanga Hrdaya: Text, English Translation, Notes, Appendices, and Index, Vol. 1: Sutra \&SariraSthana, Krishnadas Academy, Varanasi, 2000:100.

Table 1: Oral Medicines

\begin{tabular}{|c|c|c|c|c|c|c|}
\hline Medicine & Dose & Time & $\begin{array}{l}\text { Anupama (post- } \\
\text { prandial drink) }\end{array}$ & Case & Prescription & Duration \\
\hline NetrarakshaKvatha* & $5 \mathrm{~mL}$ & $\begin{array}{l}\text { Twice a day } \\
\text { before food }\end{array}$ & SukhoshnaJala & $\begin{array}{l}1 \\
3\end{array}$ & $\begin{array}{l}\text { Inpatient } \\
\text { Inpatient } \\
\text { Discharge }\end{array}$ & $\begin{array}{l}14 \text { days } \\
10 \text { days } \\
2 \text { months }\end{array}$ \\
\hline SaptamrtaLauha & 1 tablet & $\begin{array}{l}\text { Twice a day } \\
\text { after food }\end{array}$ & $\begin{array}{l}\text { NetrarakshaKvatha } \\
\text { Honey }\end{array}$ & 1 & $\begin{array}{l}\text { Inpatient } \\
\text { Discharge }\end{array}$ & $\begin{array}{l}14 \text { days } \\
2 \text { months }\end{array}$ \\
\hline MedhyaRasayanam* & 1 tablet & $\begin{array}{l}\text { 9:45am } \\
\text { After break- } \\
\text { fast }\end{array}$ & $\begin{array}{l}\text { SukhoshnaJala } \\
\text { Honey }\end{array}$ & $\mathbf{1}$ & $\begin{array}{l}\text { Inpatient } \\
\text { Discharge }\end{array}$ & $\begin{array}{l}14 \text { days } \\
2 \text { months }\end{array}$ \\
\hline Hrsva Capsule* & 1 capsule & $\begin{array}{l}\text { Twice a day } \\
\text { after food }\end{array}$ & SukhoshnaJala & $\mathbf{1}$ & Discharge & 2 months \\
\hline SaptamrtaGhrta* & 1 tablespoon & $\begin{array}{l}\text { Twice a day } \\
\text { after food }\end{array}$ & SukhoshnaJala & $\mathbf{1}$ & Discharge & 2 months \\
\hline VainateyaGhrta* & 1 tablespoon & $\begin{array}{l}\text { Twice a day } \\
\text { after food }\end{array}$ & SukhoshnaJala & 3 & $\begin{array}{l}\text { Inpatient } \\
\text { Discharge } \\
\text { Inpatient } \\
\text { Discharge }\end{array}$ & $\begin{array}{l}19 \text { days } \\
2 \text { months } \\
10 \text { days } \\
2 \text { months }\end{array}$ \\
\hline Mustarishta & $5 \mathrm{~mL}$ & $\begin{array}{l}\text { Twice a day } \\
\text { after food }\end{array}$ & Khadirarishta & 2 & $\begin{array}{l}\text { Inpatient } \\
\text { Discharge }\end{array}$ & $\begin{array}{l}19 \text { days } \\
2 \text { months }\end{array}$ \\
\hline Khadirarishta & $5 \mathrm{~mL}$ & & Mustarishta & & $\begin{array}{l}\text { Inpatient } \\
\text { Discharge }\end{array}$ & $\begin{array}{l}19 \text { days } \\
2 \text { months }\end{array}$ \\
\hline $\begin{array}{l}\text { Gopicandanadi } \\
\text { Gutika }\end{array}$ & $\begin{array}{l}1 \text { tablet } \\
1 \text { tablet }\end{array}$ & $\begin{array}{l}10 \text { am } \\
\text { Twice a day } \\
\text { after food }\end{array}$ & Tulasi, Honey & 2 & $\begin{array}{l}\text { Inpatient } \\
\text { Discharge }\end{array}$ & $\begin{array}{l}19 \text { days } \\
2 \text { months }\end{array}$ \\
\hline
\end{tabular}


External Therapies

\begin{tabular}{|c|c|c|c|c|c|}
\hline Treatment & Medicine & Case & Prescription & Duration & Procedure of Therapy \\
\hline \multicolumn{6}{|c|}{ Netra Kriyakalpa(local ophthalmic therapies) } \\
\hline \multirow[t]{3}{*}{ Ascyotana } & Ananta Ghrta* & 1 & Inpatient & 8 days & \multirow{8}{*}{$\begin{array}{l}\text { The patient lay supine and one drop of } \\
\text { the medicine was instilled into the sub- } \\
\text { conjunctival sac. The patient was asked to } \\
\text { slowly rotate the eyes after installation with } \\
\text { the eyes closed. }\end{array}$} \\
\hline & JatavedhaGhrta & 3 & Inpatient & 6 days & \\
\hline & & & Discharge & 2 months & \\
\hline \multirow[t]{5}{*}{ Anjana } & Sunetra Junior* & 1 & Discharge & 2 months & \\
\hline & Netra Sudha & 2 & Inpatient & 17 days & \\
\hline & Netra Prabha & 2 & Discharge & 2 months & \\
\hline & Netramrtam & 3 & Inpatient & 6 days & \\
\hline & & & Discharge & 2 months & \\
\hline Drishti Prasadana & $\begin{array}{l}\text { Kshirabala } 21 \text { Avartana- } \\
\text { Taila }\end{array}$ & 2 & Inpatient & 5 days & $\begin{array}{l}\text { The lukewarm medicine was taken and } \\
\text { massaged over the forehead and the upper } \\
\text { and lower eyelids from the inner canthus } \\
\text { to the outer canthus; the inner aspect of } \\
\text { the maxilla, outer canthus, inner canthus, } \\
\text { supra-orbital margins, and eyebrows using } \\
\text { the thumb and index fingers for } 2-3 \text { minutes } \\
\text { each. Adequate pressure was applied to each } \\
\text { of the points. }\end{array}$ \\
\hline \multirow[t]{2}{*}{ Eye Massage } & & 1 & Inpatient & 9 days & \multirow{3}{*}{$\begin{array}{l}2 \text { drops of lukewarm oil were applied to the } \\
\text { eyelids and massaged. }\end{array}$} \\
\hline & & & Discharge & 2 months & \\
\hline Eye Picu & Ananta Ghrta & 2 & & 3 days & \\
\hline Tarpana & $\begin{array}{l}\text { JatavedhaGhrta* and } \\
\text { KasyapaGhrta* }\end{array}$ & 3 & Inpatient & 4 days & \multirow{3}{*}{$\begin{array}{l}\text { A circular fence was constructed around } \\
\text { the orbits using Masha flour and water. The } \\
\text { medicine, made lukewarm, was poured into } \\
\text { the cavities. The patient was asked to blink } \\
\text { frequently. }\end{array}$} \\
\hline MahaTarpana $^{\wedge}$ & $\begin{array}{l}\text { JatavedhaGhrta* and } \\
\text { Ananta Ghrta }\end{array}$ & 1 & Inpatient & 6 days & \\
\hline LaghuTarpana $^{\wedge}$ & Ananta Ghrta & 2 & & 3 days & \\
\hline \multirow[t]{2}{*}{ Anna Lepa } & SashtikaSali & 1 & Inpatient & 6 days & \multirow{2}{*}{$\begin{array}{l}\text { A paste of SashtikaSali made warm was ap- } \\
\text { plied over the eyelids. }\end{array}$} \\
\hline & & 2 & & 5 days & \\
\hline \multicolumn{6}{|c|}{ Treatments for the Head } \\
\hline Talapoticchil & $\begin{array}{l}\text { Bala, Vidari, Asvagandha, } \\
\text { and KacchuradiCurna- } \\
\text { mixed with Balasvagand- } \\
\text { hadiTaila }\end{array}$ & 1 & Inpatient & 7 days & $\begin{array}{l}\text { A paste prepared from } 30 g \text { of herbal powder } \\
\text { and } 6 \text { omL of herbal decoction was applied } \\
\text { over a steamed plantain leaf. } \\
\text { This leaf is then placed with the paste in- } \\
\text { wards over the patient's head and tied down } \\
\text { using a Cora cloth. }\end{array}$ \\
\hline Siroveshtana $^{\wedge}$ & $\begin{array}{l}\text { Powder of Balaand Vida- } \\
\text { rimixed with Kacchuradi- } \\
\text { Curnaand Balasvagand- } \\
\text { hadiTaila }\end{array}$ & 1 & Inpatient & 5 days & $\begin{array}{l}\text { A semisolid paste prepared by mixing } 45 \mathrm{~g} \\
\text { of all ingredients with the desired liquid } \\
\text { medium was smeared over a Cora cloth and } \\
\text { applied to the head (area with the paste fac- } \\
\text { ing inwards) in the following manner: } \\
\text { One end of the cloth was anchored above } \\
\text { the right ear. } \\
\text { The cloth was wrapped over the forehead } \\
\text { above the eyebrows and towards the left ear. } \\
\text { From the left ear, the cloth was wrapped } \\
\text { around the back of the head and brought } \\
\text { upwards around the head while the vertex is } \\
\text { avoided. } \\
\text { The other end of the cloth was applied to the } \\
\text { top of the head. }\end{array}$ \\
\hline
\end{tabular}




\begin{tabular}{|c|c|c|c|c|c|}
\hline Treatment & Medicine & Case & Prescription & Duration & Procedure of Therapy \\
\hline Sirodhara & BalasvagandhadiTaila & 2 & Inpatient & 7 days & $\begin{array}{l}\text { The patient lay supine on the treatment } \\
\text { table. A thin cloth band was tied around the } \\
\text { forehead. A pot with an } 8 \mathrm{~mm} \text { hole in the } \\
\text { centre of the bottom was suspended above } \\
\text { the patient's head with ropes. The lukewarm } \\
\text { was poured into the pot and was allowed to } \\
\text { drain through the hole onto the patient's } \\
\text { head. }\end{array}$ \\
\hline Siro Picu & SasankaTaila & 3 & Inpatient & 7 days & $\begin{array}{l}\text { A piece of cotton gauze was dipped in luke- } \\
\text { warm oil and placed over the bregma. }\end{array}$ \\
\hline
\end{tabular}

